(c) American Dairy Science Association, 2003.

\title{
Potential Effects of Accumulating Environmental Policies on Dutch Dairy Farms
}

\author{
P. B. M. Berentsen and M. Tiessink \\ Wageningen University, Farm Management Group \\ Hollandseweg 1, 6706 KN Wageningen \\ The Netherlands
}

\section{ABSTRACT}

Consequences for farm management, environment, and economics of environmental policies for Dutch dairy farms were examined through modeling with two policies applied successively to typical dairy farms. Both policies aim to decrease nutrient losses in the soil. The first policy, the Mineral Accounting System (MINAS), is a farm gate balance approach that was introduced in 1998. Acceptable surpluses and levies are gradually tightened in this system until final standards are used in 2003. The second policy was developed to comply with the European Union Nitrate Directive and is called the Manure Transfer Agreement System (MTAS). This system links production and use of animal manure. Farms that produce more manure than the amount that can be applied on their own land according to standards are obliged to have a contract with a farmer who is willing to apply the surplus of manure on his farm. This system will be first applied in 2002 and final standards will be used in 2003. Results of the MINAS policy show finetuning of protein feeding especially by replacing grass in summer rations by maize silage and low protein concentrate. Another general result of MINAS is decreased use of $\mathrm{N}$-fertilizer on grassland. As a consequence, division of the area between maize silage and grassland is adjusted. Income drop ranges from $€ 1400$ to 4800 ( 5 to $18 \%$ ). Mineral Accounting System N surpluses drop by 45 to $113 \mathrm{~kg} / \mathrm{ha}$ ( 23 to $37 \%$ ). Adding MTAS is an incentive for more grassland as grassland has a higher manure application standard. Particularly for intensive farms, MTAS leads to high extra costs (€2600). However, expected environmental improvement is negligible. Therefore, from an environmental point of view there is no logic in adding the MTAS.

(Key words: environment, economy, policy)

Received July 1, 2002.

Accepted August 22, 2002.

Corresponding author: Paul Berentsen; e-mail: Paul.Berentsen@ wur.nl.

\begin{abstract}
Abbreviation key: MINAS = Mineral Accounting System, $\mathbf{M T A S}=$ Manure Transfer Agreement System, $\mathbf{N}_{\text {min }}$ $=$ mineral nitrogen.
\end{abstract}

\section{INTRODUCTION}

Animal density in the Netherlands is high compared with other western countries because of historically low prices of concentrates and inorganic fertilizers (Ketelaars and van der Meer, 1998) leading to high amounts of imported feed. In the early nineties the dairy sector in the Netherlands imported $45 \%$ of the feed requirements (Tamminga, 1992). The result is high levels of undigested and unutilized feed residues entering the environment through fecal and urinary excretion. This has led to leaching of nitrates and phosphates, which affects ground water quality and surface water quality (Oenema and Roest, 1998; Oenema et al., 1998).

To tackle these problems, the Dutch government developed policies from 1987 to the present. Until 1998, excessive use of animal manure was regulated by application standards. In 1998, the Mineral Accounting System (MINAS) was introduced to reduce surpluses of nitrogen $(\mathrm{N})$ and phosphate $\left(\mathrm{P}_{2} \mathrm{O}_{5}\right)$ (Aarts et al., 2000). Starting in 2002 the Manure Transfer Agreement System (MTAS) was added as an additional policy to avoid leaching of nutrients from animal manure.

Normative modeling at farm level is one way to determine the effects of management measures on the environment. The effect of management measures on the environment was studied by Rotz et al. (1999), Dunlap et al. (2000), and Kohn et al. (1997). Policy-oriented studies are especially prevalent in EU countries where the EU pressure on national governments to decrease nitrate leaching to ground water is high (Berentsen et al., 1992; Rigby and Young, 1996; Van der Ven, 1996; Van Huylenbroek et al., 2000). Because strict environmental policies that apply to agriculture are relatively new, empirical research on the effect of policies on farm management and the environment is relatively scarce. For Dutch dairy farming an in-depth analysis of the first years' effects of MINAS was reported by Ondersteijn (2002). 
The objective of this modeling study was to determine the effects of adapting to current environmental policies for dairy farms that differ in intensity. Moreover, the environmental effectiveness of applying two policies in order to achieve one goal is examined.

\section{MATERIALS AND METHODS}

\section{Policies for Decreasing Nutrient Losses to the Soil}

The introduction of MINAS in 1998 was a logical step in the sequence of environmental policies in the Netherlands aimed at decreasing nutrient losses to the soil. Before MINAS, the environmental impact on the soil was limited by the so-called Phosphate Standards. With phosphate standards, manure production on the farm was linked to application in the soil. Manure production per animal, measured in kilograms of phosphate, was considered fixed in this system. For grassland and fodder crops, different standards determined the maximum use of manure. A surplus of manure had to be transported to farms that could apply this manure within the standards. Although the system was quite rigid, it did not influence specialized dairy farming in the Netherlands much because of the relatively high application standards (Berentsen et al., 1992). The environmental focus shifted towards nitrogen as a result of the Nitrate Directive of the European Union (European Commission, 1991) stating a maximum acceptable level of $50 \mathrm{mg}$ of nitrate $\left(\mathrm{NO}_{3}\right)$ per liter ground water to ensure the safety of drinking water. Research in the mid-nineties showed that this level was exceeded in many agricultural areas in the Netherlands (De Walle and Sevenster, 1998; Fraters et al., 1998). The Mineral Accounting System was developed to tackle problems resulting from both nitrogen and phosphate losses to the soil in a more sophisticated way.

The Mineral Accounting System is a farm gate balance approach. Farmers are required to account for nutrient flows that enter and leave the farm through the farm gate. The difference between input and output is the nutrient surplus. As MINAS aims to decrease losses to the soil, the $\mathrm{N}$ surplus is corrected for gaseous losses like ammonia emission from stables. The final surplus is expressed per hectare and compared to standards expressing surpluses per hectare that are considered acceptable. The amounts of $\mathrm{N}$ and $\mathrm{P}_{2} \mathrm{O}_{5}$ exceeding the acceptable surpluses are penalized with a levy per $\mathrm{kg}$ of $\mathrm{N}$ and $\mathrm{P}_{2} \mathrm{O}_{5}$ respectively. As from the introduction of MINAS in 1998, acceptable surpluses and levies were gradually tightened till final standards will be used in 2003 (Table 1). As can be seen from Table 1, acceptable surpluses differ depending on the use of the land and for $\mathrm{N}$ also on the vulnerability of the land concerning leaching. MINAS has a number of shortcomings like not including atmospheric $\mathrm{N}$ deposition, biological fixation of $\mathrm{N}$ and $\mathrm{P}_{2} \mathrm{O}_{5}$ fertilizer as inputs to the system. However, MINAS is considered a step forward in environmental policy because the resulting $\mathrm{N}$ surplus is a better indicator for nutrient contamination of ground water than nutrient input via manure (Schröder et al., 2003). A wholefarm balance approach has the advantage of giving autonomy to farmers to determine how and where they will reduce their surpluses (Hanegraaf and Den Boer, 2003), but application standards leave only a very limited number of measures farmers can take to comply with the standards.

Despite the sophisticated system, the EU did not accept MINAS as a system that complies with the European Union's Nitrate Directive. The main reason was that MINAS was considered not to address the application of manure sufficiently (Ondersteijn et al., 2002). To satisfy the EU, the Manure Transfer Agreement System (MTAS) was developed and in 2002 this system was implemented in addition to MINAS. MTAS is based on standards for $\mathrm{N}$ production in manure and for $\mathrm{N}$ application from manure on land (see Table 1 for the application standards for 2003). If a farm produces more $\mathrm{N}$ in manure than can be applied to the farm land according to the standards, the farmer has to have a manure transfer agreement with any farmer with excess "application room," showing that this farmer is willing to apply the surplus of manure on his land. However, there is no direct link between the obligation to have a manure transfer agreement and actual disposal of manure (Ministry of Agriculture, 2001). A farmer is not required to dispose manure and he will not do so as long as he can apply the manure on his own land within the acceptable surpluses of MINAS. As in the Netherlands, many farms have a shortage of "application room", manure transfer agreements are scarce, so manure producers have to pay for agreements. MTAS was introduced in 2002. For 2002, only $85 \%$ of the $\mathrm{N}$ manure production on farms had to be covered by application of manure on the own farm and, if necessary, by manure transfer agreements. For 2003 , the amount increases to $95 \%$. For 2002, manure transfer agreements covered 91 million $\mathrm{kg}$ of $\mathrm{N}$, which is $20 \%$ of the total $\mathrm{N}$ manure production in the Netherlands (Van Staalduinen et al., 2002). A first indication for an average price paid is €0.78 per $\mathrm{kg} \mathrm{N}$ (Van der Kamp, 2002). This price is paid for the agreement only, not for disposal of manure. The price a manure producer has to pay for disposal of manure varies between $€ 8.50$ and $€ 15.50$ per metric ton of manure (Philipsen et al., 2001).

\section{The Dairy Farm Model}

The model that is used to determine the effects of the environmental policies is a whole farm linear program- 
Table 1. Acceptable nutrient surpluses and levies within the Mineral Accounting System and application standards within the Manure Transfer Agreement System (2003).

\begin{tabular}{lccc}
\hline & & \multicolumn{2}{c}{ Nitrogen } \\
\cline { 3 - 4 } & & All soils & $\begin{array}{r}\text { Vulnerable } \\
\text { sandy soils }\end{array}$ \\
\hline Acceptable surpluses $(\mathrm{kg} / \mathrm{ha})$ & & & \\
Grassland & 20 & 180 & 140 \\
Arable land & 20 & 100 & 60 \\
Conservation areas & 10 & 50 & 50 \\
Levies $€^{1 / \mathrm{kg}}$ & 9 & 2.30 & 2.30 \\
Application standards (kg N/ha) & & & 250 \\
Grassland & & 250 & 170 \\
Arable land & & 170 & \\
\hline
\end{tabular}

${ }^{1} € 1 \sim$ US $\$ 1$.

ming model. The objective function maximizes labor income (i.e., the remuneration for family labor and management that is left after all other costs have been paid).

The central element in the model is a dairy cow, calving in February, with a fixed milk production. A minimal ratio is required between the number of young stock and the number of dairy cows to guarantee replacement of dairy cows. Surplus heifers can be sold. The feeding part of the model consists of four parts. The dairy cows and young stock are fed separately, and a division is made between summer, when cows and young stock can graze, and winter, when livestock are kept indoors. For dairy cows, feeding constraints reflect demand and supply of energy and protein, DMI capacity, and demand for fiber in the ration. Milk production, energy requirements and feed intake capacity in the summer and winter periods are determined using formulas of Groen (1988). For protein, the DVE/OEB system is used (Tamminga et al., 1994). Protein requirements are calculated using formulas of the Central Bureau for Livestock Feeding (1995). Because dietary requirements of young stock are usually less complicated, constraints on feeding pertain to only energy and protein. Feed for dairy cows and young stock consists of grazed and conserved grass and maize silage produced on the farm, three types of purchased concentrates that differ in protein content, dried beet pulp, and purchased maize silage.

The land can be used for growing grass or maize silage. Grass can be produced in the model at five rates of mineral nitrogen $\left(\mathbf{N}_{\mathbf{m i n}}\right)$ from fertilizer and manure (100, $200,300,400$ and $500 \mathrm{~kg}$ per ha per yr) to include decreasing marginal production with increasing $\mathrm{N}_{\min }$ rates. Grass can be used either for grazing by dairy cows and young stock or for mowing for silage to be fed to either category of stock. The area of grassland and division between grazing and mowing is dependent on the interactions among animal requirements, season of the year, price of concentrates and price and availability of other forages. These interactions are all considered in the opti- mization process. To maintain the quality of grass a minimum percentage of mowing is necessary. This is modeled by requiring a minimum amount of grass silage of $2 \mathrm{~kg}$ DM per cow per day in the winter ration.

Modeling of maize production is less complex. Above an optimal nutrient rate, production response to nutrients is low (Aarts and Middelkoop, 1990) so that only one nutrient rate is used. Maize silage can be grown as summer or winter feed for dairy cows, or as winter feed for young stock.

Nutrients for plant production can be supplied by fertilizer or by manure. The model estimates MINAS balances for $\mathrm{N}$ and $\mathrm{P}_{2} \mathrm{O}_{5}$ at the farm level based on nutrient inputs and outputs. For a more detailed description of the model see Berentsen and Giesen (1995).

The initial farm situation is specified by the righthand side values for land, milk quota and family labor and by farm-specific coefficients representing milk production per cow and grass production per hectare.

\section{Typical Farms}

Choice of farms is based on a report called Typical Dutch (Reijneveld et al., 2000). In this report specialized dairy farms in the Netherlands are clustered according to region, soil type and intensity. Farm data used for clustering are from 1997 and 1998. More than half of the specialized dairy farms in the Netherlands are located on sandy soil where environmental problems are highest. Consequently, averages of different intensity clusters on sandy soil were chosen as typical farms. The different classes of intensity, based on yearly milk production per hectare, were 10,000 to $12,000 \mathrm{~kg} / \mathrm{ha}, 12,000$ to 15,000 $\mathrm{kg} / \mathrm{ha}$ and $>15,000 \mathrm{~kg} / \mathrm{ha}$. Fixed assets and productivity characteristics of the resulting farms are in Table 2. These data were used to model the farms. Because average productivity of maize silage appeared to differ only slightly among the farms, the average gross production of 85,050 MJ NEL was used for all farms. 
Table 2. Characteristics of three typical dairy farms on sandy soils, differing in intensity.

\begin{tabular}{lccc}
\hline & $\begin{array}{l}\text { Low } \\
\text { intensity } \\
\text { farm }\end{array}$ & $\begin{array}{l}\text { Medium } \\
\text { intensity } \\
\text { farm }\end{array}$ & $\begin{array}{l}\text { High } \\
\text { intensity } \\
\text { farm }\end{array}$ \\
\hline $\begin{array}{l}\text { Intensity (kg milk quota/ha) } \\
\begin{array}{l}\text { Total area (ha) } \\
\text { of which: }\end{array}\end{array}$ & 11,300 & 13,400 & 19.000 \\
$\quad$ grassland (ha) & 36 & 31 & 24.5 \\
$\quad$ maize (ha) & 28.2 & 24.2 & 15.4 \\
Milk quota (1000 kg) & 7.8 & 6.8 & 9.1 \\
Milk production (kg/cow/year) & 406 & 416 & 476 \\
Grass production (MJ NE $/$ ha) & 7000 & 7600 & 7500 \\
N-fertilizer on grassland (kg/ha) & 54,250 & 65,385 & 66,460 \\
\hline
\end{tabular}

Additional assumptions used in the model concerned the price of manure transfer agreements (€0.78 per $\mathrm{kg}$ $\mathrm{N})$ and of manure disposal ( $€ 11.34$ per ton of manure). These prices stem from an evaluation study of the Dutch manure policy for 2003 (Van der Kamp, 2002). It was assumed that soils were not especially vulnerable to leaching. It appeared from Typical Dutch that the majority of dairy farms on sandy soils apply only day grazing for dairy cows in summer with maize silage fed in the evening. This feeding arrangement is included in the model by using limited grazing and by requiring a minimum amount of $4 \mathrm{~kg}$ DM from maize silage per cow per day in summer.

\section{RESULTS}

Farm management, environmental and economic results of the three typical farms for a base situation, the situation with MINAS-2003, and the situation with MINAS-2003 and MTAS-2003 are presented. In the base situation, no environmental policy is assumed.

\section{The Low Intensity Farm (11,300 kg milk quota/ha)}

In all situations, the numbers of dairy cows and young stock on this farm are 58 and 44 respectively. These numbers are determined by the available milk quota and milk production per cow and by the fixed replacement rate respectively.

In general, land use and dairy cow rations in the base situation are determined as follows. The amount of grass silage is minimized in the winter ration because costs of ensiling are relatively high and because grass production per ha is lower than silage maize production per ha. The uptake of fresh grass in summer by grazing is maximized because it is a cheap source of energy and protein (no harvesting costs). The maximum is determined by the DMI capacity of the cows and by the minimum requirement of $4 \mathrm{~kg}$ DM from maize silage in summer. An additional amount of concentrates fulfils the requirement for energy. The high amount of grass in the summer ration results in a high surplus of protein in the ration. For the winter ration, requirements for energy, rumen degradable protein, and intestine digestible protein finetune the composition of the ration and influence $\mathrm{N}_{\min }$ use on grassland. Higher use of $\mathrm{N}_{\min }$ results in higher protein concentrations in grass. $\mathrm{N}_{\min }$ use is also influenced by the required production of grass and together these factors determine the area of grassland. The rest of the area is used for maize silage.

Table 3 shows the resulting land use and composition of the rations for the $11,300 \mathrm{~kg}$ intensity farm. Comparison of the land use with the land use in reality (Table 2 ) shows a smaller area of grassland in favor of a greater area of maize silage. The MINAS balances show an Nsurplus of 197 and a $\mathrm{P}_{2} \mathrm{O}_{5}$-surplus of $6 \mathrm{~kg} / \mathrm{ha}$. Total revenues of $€ 163,001$ and total costs of $€ 142,755$ result in a labor income of $€ 20,246$. Marginal values of land and milk quota show the increase of labor income if one hectare of land respectively $1000 \mathrm{~kg}$ of milk quota is added to the farm. Conversely, marginal values show the amount of money that the farm can afford to pay annually to acquire these production factors without decreasing labor income.

When MINAS-2003 is included, the acceptable surplus for $\mathrm{N}$ restricts $\mathrm{N}$-input (Table 3 ). The $\mathrm{N}$ input is decreased by decreasing $\mathrm{N}$ fertilizer use on grassland. Given the lower marginal productivity at higher $\mathrm{N}$ rates, this decreases $\mathrm{N}$ surpluses per $\mathrm{kg}$ of produced grass. The resulting shortage of feed is replenished by purchasing extra concentrate. This is low protein concentrate as the summer ration is balanced for protein requirements. Furthermore, this fine-tuning results in a greater share of maize silage in the summer ration. The consequence is a greater area of maize silage. MINAS- $\mathrm{P}_{2} \mathrm{O}_{5}$ is not a problem with this low intensity keeping in mind that $\mathrm{P}_{2} \mathrm{O}_{5}$ fertilizer is not included as an input. Costs that differ are costs of ensiling roughage $(+€ 1000)$, concentrate costs $(+€ 1600)$, and fertilizer costs $(-€ 1000)$. As a result, labor income decreases by $€ 1600$. As MINAS is 
Table 3. Farm management, environmental and economic results for the low intensity dairy farm.

\begin{tabular}{|c|c|c|c|}
\hline & $\begin{array}{l}\text { Base } \\
\text { situation }\end{array}$ & MINAS- $2003^{2}$ & $\begin{array}{l}\text { MINAS-2003 + } \\
\text { MTAS- } 2003^{3}\end{array}$ \\
\hline \multicolumn{4}{|l|}{ Land use } \\
\hline Grassland (ha) & 24.8 & 23.0 & 23.5 \\
\hline Maize silage (ha) & 11.2 & 13.0 & 12.5 \\
\hline Nmin on grassland $(\mathrm{kg} / \mathrm{ha})$ & 334 & 257 & 255 \\
\hline Concentrate purchased (1000 $\left.\mathrm{MJ} \mathrm{NE}_{\mathrm{L}}\right)$ & 729 & 779 & 797 \\
\hline \multicolumn{4}{|l|}{ Winter ration $(\mathrm{kg}$ of $\mathrm{DM} / \mathrm{d}$ per cow $)$} \\
\hline Grass silage & 2.0 & 2.0 & 2.0 \\
\hline Maize silage & 5.0 & 5.2 & 4.9 \\
\hline Concentrate, standard & 7.7 & 7.3 & 7.6 \\
\hline Concentrate, high protein & 0.1 & 0.4 & 0.4 \\
\hline \multicolumn{4}{|l|}{ Summer ration (kg of DM/d per cow) } \\
\hline Grass & 10.6 & 8.1 & 8.4 \\
\hline Maize silage & 4.0 & 6.0 & 5.7 \\
\hline Concentrate, standard & 2.4 & 0 & 0 \\
\hline Concentrate, low protein & 0 & 3.3 & 0.5 \\
\hline Dried beet pulp & 0 & 0 & 2.5 \\
\hline Manure transfer agreements (kg N) & $\cdots$ & $\cdots$ & 549 \\
\hline \multicolumn{4}{|l|}{ MINAS-N (kg/ha) } \\
\hline Total farm input & 269 & 224 & 225 \\
\hline Total farm output & 67 & 67 & 67 \\
\hline Correction gaseous losses & 6 & 6 & 6 \\
\hline Corrected surplus & 197 & 151 & 152 \\
\hline Acceptable surplus & $\ldots$ & 151 & 152 \\
\hline Penalized surplus & $\ldots$ & 0 & 0 \\
\hline \multicolumn{4}{|l|}{ MINAS- $\mathrm{P}_{2} \mathrm{O}_{5}(\mathrm{~kg} / \mathrm{ha})$} \\
\hline Total farm input & 34 & 37 & 31 \\
\hline Total farm output & 28 & 28 & 28 \\
\hline Surplus & 6 & 9 & 3 \\
\hline Acceptable surplus & $\ldots$ & 20 & 20 \\
\hline Penalized surplus & $\ldots$ & 0 & 0 \\
\hline \multicolumn{4}{|l|}{ Economic results $\left(€^{1}\right)$} \\
\hline Total revenues & 163,000 & 163,000 & 163,000 \\
\hline Total costs & 142,755 & 144,353 & 144,951 \\
\hline Labor income & 20,246 & 18,648 & 18,050 \\
\hline Marginal value of land (€/ha) & 378 & 667 & 861 \\
\hline Marginal value of milk quota (€/1000 kg) & 123 & 94 & 76 \\
\hline Marginal value of acceptable $\mathrm{N}$ surplus ( $€ / \mathrm{kg}$ ) & $\ldots$ & 1.35 & 1.31 \\
\hline
\end{tabular}

land based, the intensity becomes more important when including MINAS. This is shown by the marginal values of land and milk quota. Under MINAS, land becomes more valuable while the value of milk quota decreases. The marginal value of the acceptable $\mathrm{N}$ surplus shows the marginal cost of realizing the acceptable $\mathrm{N}$ surplus. It shows that for this farm it is cheaper to decrease the $\mathrm{N}$ surplus than to pay levy. This means that the levy of $€ 2.30$ is prohibitive in this case.

Adding MTAS means that manure transfer agreements have to be made for $549 \mathrm{~kg}$ of $\mathrm{N}$ (Table 3). MTAS pushes the farm plan in the direction of more grassland because MTAS application standards of grassland are higher. To stay within the acceptable $\mathrm{N}$ surplus dried beet pulp enters the summer ration. The very low protein content of dried beet pulp compensates for extra protein supplied with the increase of fresh grass. As the $\mathrm{P}_{2} \mathrm{O}_{5}$ content of dried beet pulp is also very low, the $\mathrm{P}_{2} \mathrm{O}_{5}$ surplus decreases. Total costs increase by $€ 600$. This is mainly due to manure transfer agreements $(€ 430)$. The rest is the result of the changes in the farm plan. Finally, like MINAS, MTAS increases marginal value of land and decreases marginal value of milk quota.

\section{The Medium Intensity Farm $(13,400 \mathrm{~kg}$ milk quota/ha)}

Given the area of land, available milk quota, milk production per cow and replacement rates, the numbers of dairy cows and young stock are 55 and 40 respectively. Due to the higher intensity of this farm, more roughage production per hectare is required. This is the reason 
Table 4. Farm management, environmental and economic results for the medium intensity dairy farm.

\begin{tabular}{|c|c|c|c|}
\hline & $\begin{array}{l}\text { Base } \\
\text { situation }\end{array}$ & MINAS- $2003^{2}$ & $\begin{array}{l}\text { MINAS-2003 + } \\
\text { MTAS- } 2003^{3}\end{array}$ \\
\hline \multicolumn{4}{|l|}{ Land use } \\
\hline Grassland (ha) & 19.8 & 22.4 & 22.4 \\
\hline Maize silage (ha) & 11.2 & 8.6 & 8.6 \\
\hline Nmin on grassland (kg/ha) & 400 & 254 & 254 \\
\hline Concentrate purchased $\left(1000 \mathrm{MJ} \mathrm{NE}_{\mathrm{L}}\right)$ & 787 & 814 & 814 \\
\hline Maize silage purchased $\left(1000 \mathrm{MJ} \mathrm{NE}_{\mathrm{L}}\right)$ & 0 & 192 & 192 \\
\hline \multicolumn{4}{|l|}{ Winter ration (kg of DM/d per cow) } \\
\hline Grass silage & 2.0 & 2.0 & 2.0 \\
\hline Maize silage & 5.8 & 5.7 & 5.7 \\
\hline Concentrate, standard & 7.4 & 7.5 & 7.5 \\
\hline Concentrate, high protein & 0.5 & 0.5 & 0.5 \\
\hline \multicolumn{4}{|l|}{ Summer ration (kg of DM/d per cow) } \\
\hline Grass & 10.0 & 9.9 & 9.9 \\
\hline Maize silage & 4.0 & 4.0 & 4.0 \\
\hline Concentrate, standard & 4.0 & 0 & 0 \\
\hline Concentrate, low protein & 0 & 4.3 & 4.3 \\
\hline Dried beet pulp & 0 & 0 & 0 \\
\hline Manure transfer agreements (kg N) & & $\ldots$ & 1002 \\
\hline \multicolumn{4}{|l|}{ MINAS-N (kg/ha) } \\
\hline Total farm input & 312 & 249 & 249 \\
\hline Total farm output & 79 & 79 & 79 \\
\hline Correction gaseous losses & 12 & 12 & 12 \\
\hline Corrected surplus & 221 & 158 & 158 \\
\hline Acceptable surplus & $\ldots$ & 158 & 158 \\
\hline Penalized surplus & . . & 0 & 0 \\
\hline \multicolumn{4}{|l|}{ MINAS- $\mathrm{P}_{2} \mathrm{O}_{5}(\mathrm{~kg} / \mathrm{ha})$} \\
\hline Total farm input & 45 & 51 & 51 \\
\hline Total farm output & 33 & 33 & 33 \\
\hline Surplus & 11 & 18 & 18 \\
\hline Acceptable surplus & $\ldots$ & 20 & 20 \\
\hline Penalized surplus & . . & 0 & 0 \\
\hline \multicolumn{4}{|l|}{ Economic results $\left(€^{1}\right)$} \\
\hline Total revenues & 165,600 & 165,600 & 165,600 \\
\hline Total costs & 139,273 & 140,669 & 141,450 \\
\hline Labor income & 26,327 & 24,931 & 24,150 \\
\hline Marginal value of land (€/ha) & 733 & 893 & 1005 \\
\hline Marginal value of milk quota (€/1000 kg) & 192 & 176 & 167 \\
\hline Marginal value of acceptable $N$ surplus $(€ / \mathrm{kg})$ & $\ldots$ & 1.32 & 1.21 \\
\hline
\end{tabular}

that the $\mathrm{N}_{\text {min }}$ level on grassland is as high as $400 \mathrm{~kg}$ in the base situation (Table 4). Cow rations are highly comparable with that of the previous farm. Labor income for this farm is $€ 6000$ higher. This higher income is the result of a higher total milk production leading to higher revenues. On the costs side the lower number of cows (with a higher production per cow) leads to lower costs directly attributable to the number of animals, like costs of housing, health care, breeding, etc. The smaller land area and the lower numbers of animals results in zero costs for variable, non-family labor. These costs were around $€ 1500$ for the previous farm. Finally, due to the smaller land area, costs of purchased feed (concentrates) are higher, but this effect is moderate because productivity of grassland is considerably higher on this farm. Sum- marizing, the economic effect of higher plant and animal productivity and a $2 \%$ higher milk quota outweighs the economic effect of a 14\% greater land area by $€ 6000$. Both the marginal values for land and quota are higher than on the previous farm. In general, the marginal value for land increases with increasing intensity (land is becoming more scarce) while the marginal value for milk quota decreases. However, due to the higher plant and animal productivity both marginal values are higher in this case.

Inclusion of MINAS-2003 results in a decrease of the $\mathrm{N}_{\min }$ level on grassland and in a shift to more grassland, which is in contrast with the previous farm. This is due to the higher productivity of grassland on this farm. However, as this farm is more intensive, the shift to 
Table 5. Farm management, environmental and economic results for the high intensity dairy farm.

\begin{tabular}{|c|c|c|c|}
\hline & $\begin{array}{l}\text { Base } \\
\text { situation }\end{array}$ & MINAS- $2003^{2}$ & $\begin{array}{l}\text { MINAS- } 2003+ \\
\text { MTAS- } 2003^{3}\end{array}$ \\
\hline \multicolumn{4}{|l|}{ Land use } \\
\hline Grassland (ha) & 22.8 & 23.8 & 23.8 \\
\hline Maize silage (ha) & 1.7 & 0.7 & 0.7 \\
\hline Nmin on grassland $(\mathrm{kg} / \mathrm{ha})$ & 400 & 270 & 270 \\
\hline Concentrate purchased (1000 MJ NE $\mathrm{N}_{\mathrm{L}}$ ) & 925 & 1012 & 1012 \\
\hline Maize silage purchased $\left(1000 \mathrm{MJ} \mathrm{NE}_{\mathrm{L}}\right)$ & 853 & 934 & 934 \\
\hline \multicolumn{4}{|l|}{ Winter ration (kg of DM/d per cow) } \\
\hline Grass silage & 2.0 & 2.0 & 2.0 \\
\hline Maize silage & 5.6 & 5.7 & 5.7 \\
\hline Concentrate, standard & 7.6 & 7.5 & 7.5 \\
\hline Concentrate, high protein & 0.4 & 0.5 & 0.5 \\
\hline \multicolumn{4}{|l|}{ Summer ration (kg of DM/d per cow) } \\
\hline Grass & 9.9 & 8.9 & 8.9 \\
\hline Maize silage & 4.0 & 4.0 & 4.0 \\
\hline Concentrate, standard & 4.0 & 0 & 0 \\
\hline Concentrate, low protein & 0 & 0 & 0 \\
\hline Dried beet pulp & 0 & 4.7 & 4.7 \\
\hline Manure transfer agreements $(\mathrm{kg} \mathrm{N})$ & & & 3284 \\
\hline Manure disposal (metric tons) & 0 & 230 & 230 \\
\hline \multicolumn{4}{|l|}{ MINAS-N (kg/ha) } \\
\hline Total farm input & 467 & 391 & 391 \\
\hline Total farm output & 114 & 151 & 151 \\
\hline Correction gaseous losses & 46 & 46 & 46 \\
\hline Corrected surplus & 307 & 194 & 194 \\
\hline Acceptable surplus & $\ldots$ & 178 & 178 \\
\hline Penalized surplus & $\ldots$ & 16 & 16 \\
\hline \multicolumn{4}{|l|}{ MINAS- $\mathrm{P}_{2} \mathrm{O}_{5}(\mathrm{~kg} / \mathrm{ha})$} \\
\hline Total farm input & 93 & 82 & 82 \\
\hline Total farm output & 48 & 62 & 62 \\
\hline Surplus & 45 & 20 & 20 \\
\hline Acceptable surplus & $\ldots$ & 20 & 20 \\
\hline Penalized surplus & $\ldots$ & 0 & 0 \\
\hline \multicolumn{4}{|l|}{ Economic results $\left(€^{1}\right)$} \\
\hline Total revenues & 190,627 & 190,627 & 190,627 \\
\hline Total costs & 163,449 & 167,313 & 169,872 \\
\hline Levy & & 906 & 906 \\
\hline Labor income & 27,179 & 22,408 & 19,849 \\
\hline Marginal value of land (€/ha) & 790 & 1200 & 1332 \\
\hline Marginal value of milk quota $(€ / 1000 \mathrm{~kg})$ & 107 & 76 & 49 \\
\hline Marginal value of acceptable $\mathrm{N}$ surplus $(€ / \mathrm{kg})$ & $\ldots$ & 2.30 & 2.30 \\
\hline
\end{tabular}

more grassland and the decrease of the $\mathrm{N}_{\min }$ level causes shortage of roughage. Consequently, a small amount of maize silage is purchased. Like the previous farm, rations are balanced for protein requirement and the $\mathrm{N}$ surplus meets with the acceptable surplus. Labor income decreases by $€ 1400$ compared to the base situation.

Inclusion of both MINAS and MTAS does not change the farm plan or the MINAS-balances. Labor income decreases by $€ 781$ due to costs of manure transfer agreements.

\section{The High Intensity Farm (19,000 kg milk quota/ha)}

For this farm, the numbers of dairy cows and young stock are 63 and 48 respectively. Due to the high inten- sity and the high requirement for grass this farm uses the major part of the land as grassland (Table 5). Comparison with the farm characteristics (Table 2) shows that, contrary to the previous farms, this farm has a much smaller area of maize land than in reality. Purchasing some 10 ha of maize silage compensates for the shortage of roughage. Rations are highly comparable with those of the previous farms. The high intensity of the farm results in relatively high MINAS-surpluses. Labor income is comparable with that of the previous farm. Apparently, from an economic point of view a $12 \%$ higher milk quota compensates for a $21 \%$ smaller area, as animal and plant productivity are almost the same.

Introduction of MINAS-2003 has considerable consequences to the high intensity farm. The MINAS-balances 
show that the $\mathrm{P}_{2} \mathrm{O}_{5}$ surplus is brought down to the acceptable level while the $\mathrm{N}$ surplus exceeds the acceptable level. First, surpluses are reduced by minimizing $\mathrm{N}$ and $\mathrm{P}_{2} \mathrm{O}_{5}$ input in the summer ration of the dairy cows. This is done by decreasing the amount of grass in the summer ration and by replacing concentrate with dried beet pulp. Second, the N level on grassland is decreased and third, 230 metric tons of manure are removed from the farm. Labor income decreases by $€ 4771$ due to higher costs of concentrates, costs of manure disposal (€2600) and the levy that has to be paid because of the MINAS N surplus. Costs of applying manure on the farm decrease by $€ 700$. These results and also marginal values of land and quota show that with MINAS-2003, intensity is becoming a problem on this farm. The marginal value of the acceptable $\mathrm{N}$ surplus is $€ 2.30$, which means that the levy is not prohibitive for this farm.

Adding MTAS-2003 does not change the farm plan nor the MINAS balances. The only effects are economic. Labor income decreases by $€ 2559$, which are the costs of the manure transfer agreements.

\section{Sensitivity Analysis}

A number of uncertain factors should be considered. The first one has to do with the location of the farms. So far it was assumed that farms were located on common sandy soil. An alternative, worst case scenario for farms as far as environmental policy is concerned, would be to assume that farms are located on sandy soils vulnerable for leaching of N. Secondly, there is uncertainty about prices of goods and services that are influenced heavily by environmental policy, like prices of manure transfer agreements and of manure disposal. Extra calculations for the situation with MINAS-2003 and MTAS-2003 were done to determine the sensitivity of the results for changes in these factors. New results are compared to those in the final situation of the previous calculations.

Assuming that farms are located on vulnerable sandy soil means that acceptable $\mathrm{N}$ surpluses go down (see Table 1). For the high intensity farm there is no effect on farm management and environmental results. This farm was already paying levies and it pays $€ 2200$ more levy. Both other farms further decrease the $\mathrm{N}$ level on grassland and buy more concentrates and maize silage (the $13,400 \mathrm{~kg}$ intensity farm) to stay within the acceptable $\mathrm{N}$ surpluses. The effect on labor income is $€ 2500$ and $€ 2000$ for the low and for the medium intensity farm, respectively. The effect is higher for the first farm because of the lower animal and plant productivity.

If the price of manure transfer contracts would be doubled, there is a higher area of grassland used as the $\mathrm{N}$ application standards for grassland are higher than for arable land. However, changing arable land to grass- land is limited by MINAS that requires fine-tuning of the rations especially with regard to protein requirement and supply. So, all farms slightly increase the area of grassland. On the high intensity farm this is accompanied by a further decrease of the $\mathrm{N}_{\min }$ level on grassland. The result is a decrease of the amount of $\mathrm{N}$ under the manure transfer agreement. Labor income decreases by $€ 230, € 700$ and $€ 2425$ for the three farms respectively. Effects on MINAS surpluses are negligible.

Increasing the price of manure disposal by $20 \%$, which results in the high end of the range of manure disposal prices as given by Philipsen et al. (2001), only influences the high intensity farm as this is the only farm that disposes manure. There is no effect on farm plan. The only effect is an income decrease by $€ 1022$ due to the higher costs of manure disposal.

\section{DISCUSSION}

Results show that the low and medium intensity dairy farms can cope with MINAS-2003 by fine-tuning feeding and fertilizing without losing more than $8 \%$ of their income. The high intensity farm faces an income loss of $18 \%$ as this farm depends on the relatively expensive measure of manure disposal. Generally, it can be stated that good nutrient management (i.e., feeding and fertilizing on the edge) can bring down nutrient losses to a certain level at reasonable costs, but given the tight acceptable surpluses in 2003, especially high intensity farms cannot escape from expensive measures.

MINAS-2003 is fully effective as far as the two less intensive farms are concerned in the sense that $\mathrm{N}$ surpluses are brought down to the acceptable level. Given the intensity of these farms, $\mathrm{P}_{2} \mathrm{O}_{5}$ surpluses are not a problem. For the high intensity farm, MINAS-2003 is not fully effective as it shows to be economically profitable to pay levies on $\mathrm{N}$ surplus instead of further decreasing $\mathrm{N}$ surpluses. This conflicts with the basic idea of the government that levies should be prohibitive (Brinkhorst and Pronk, 1999), which means that it should not be economically attractive to pay levies instead of decreasing surpluses. Margin analysis shows that in this particular case with a manure disposal price of $€ 13.00$ per metric ton, the levy on unacceptable $\mathrm{N}$ surpluses should be $20 \%$ higher to become prohibitive.

MTAS-2003 does affect farms, but not in the sense that environmental results improve. On the low intensity farm, the farm plan shifts towards more grassland because the manure application standards for grassland are higher. On the other two farms, the farm plan already shifted towards more grassland as a result of MINAS. For these farms there is only an economic effect. For the high intensity farm, MTAS results in a further decrease of labor income by $9 \%$. As the decrease of income 
is not accompanied by better environmental results, MTAS merely functions as a mechanism to transfer income from livestock farmers to arable farmers.

Changing the ration in order to meet herd nutritional requirements with less $\mathrm{N}$-input through purchased feed appears to be helpful to reduce manure $\mathrm{N}$ excretion and consequently $\mathrm{N}$ surpluses (see also Rotz et al., 1999 and Dou et al., 1996). In the model that was used here, it is assumed that cows could exactly be fed according to protein standards. This can be realized if animals are fed individually. However, if cows are group fed, for example, roughage, it is often impossible to feed exactly according to protein standards. This means that, in practice, generally a surplus of protein is fed as a kind of safety margin. On average, this means extra consumption of protein and consequently higher $\mathrm{N}$ surpluses. As a result it will take more effort and more costs to meet the acceptable surpluses. A safety margin of $100 \mathrm{~g}$ of intestine digestible protein per day (6 to $7 \%$ ) and $200 \mathrm{~g}$ rumen degradable protein (Berentsen et al., 1996) means that labor income decreases by an extra $€ 1350$ and $€ 2584$ for the medium and high intensity farms, respectively, as a result of the environmental policies. On the low intensity farm, there is hardly any influence.

The farm data used in this research, including the data on productivity, are from 1997 to 1998 . Since then, animal and plant productivities have improved. Productivity improvement means a better input/output ratio and this includes a more efficient use of nutrients and lower surpluses (Tamminga, 1992; Berentsen and Giesen, 1997). The consequences for 2003 calculations will be that it will take lower costs to meet the acceptable surpluses.

\section{CONCLUSIONS}

Main farm management effects of MINAS for Dutch dairy farms are (1) fine tuning of protein feeding especially by replacing grass in the summer ration by corn silage and low protein concentrate and (2) a decrease in the $\mathrm{N}$ fertilizer use on grassland. This is followed by a change in land use depending on grassland productivity and the drop in $\mathrm{N}$ fertilizer use. Low grassland productivity and a moderate drop in $\mathrm{N}$ fertilizer use leads to more maize silage at the expense of grassland. Higher grassland productivity and a substantial drop in $\mathrm{N}$ fertilizer use leads to more grassland to maintain grass production at a required level. The environmental effects of MINAS are a drop of the MINAS N surplus in amounts of 46 to $113 \mathrm{~kg} / \mathrm{ha}$ and a drop of the MINAS $\mathrm{P}_{2} \mathrm{O}_{5}$ surplus of $25 \mathrm{~kg} / \mathrm{ha}$ on intensive farms. The Mineral Accounting System is fully effective on farms with a lower intensity. On farms with higher intensity, the acceptable $\mathrm{N}$ surplus is exceeded, and levy is paid. Con- sequences for labor income are a decrease of $€ 1400$ to $€ 4800$.

Contrary to MINAS, the Manure Transfer Agreement System has little effect on farm management. The higher application standard of grassland is an incentive for more grassland. Income effects depend strongly on intensity, measured in animals per hectare. On intensive farms, income decreases by $€ 2600$ due to MTAS. There is no benefit to the environment by applying MTAS in addition to MINAS.

\section{ACKNOWLEDGMENTS}

The authors would like to thank Christien Ondersteijn and Lisa Holden for valuable comments on an earlier version of this paper.

\section{REFERENCES}

Aarts, H. F. M., B. Habekotte, and H. van Keulen. 2000. Phosphorus (P) management in the 'De Marke' dairy farming system. Nutrient Cycling in Agroecosystems 56:219-229.

Aarts, H. F. M., and N. Middelkoop. 1990. De invloed van bodemeigenschappen en bemesting op de opbrengst van mais en de emissies van ammoniak en nitraat. Rep. No. 131. Centre for Agrobiological Research, Wageningen, The Netherlands.

Berentsen, P. B. M., and G. W. J. Giesen. 1997. Governmental policy options for decreasing nitrogen and phosphate losses on Dutch dairy farms. Pages 175-192 in Controlling mineral emissions in European agriculture; economics, policies and the environment. E. Romstad, J. Simonsen and A. Vatn, ed. CAB International, Wallingford, United Kingdom.

Berentsen, P. B. M., G. W. J. Giesen, and J. A. Renkema. 1996. Reality and modelling: Operational validation of an environmental-economic model of a dairy farm. Wageningen Economic Paper 1996-2, Wageningen University, Wageningen, The Netherlands.

Berentsen, P. B. M., and G. W. J. Giesen. 1995. An environmentaleconomic model at farm level to analyse institutional and technical change in dairy farming, Agric. Sys. 49:153-175.

Berentsen, P. B. M., G. W. J. Giesen, and S. C. Verduyn. 1992. Manure legislation effects on income and on $\mathrm{N}, \mathrm{P}$ and $\mathrm{K}$ losses in dairy farming. Livest. Prod. Sci. 31:43-56.

Brinkhorst, L. J., and J. P. Pronk. 1999. Integrale aanpak mestproblematiek. Tweede Kamer der Staten-Generaal. vergaderjaar 1998-1999, 26 (1), 729. The Hague, The Netherlands.

Central bureau for Livestock Feeding. 1995. Voedernormen landbouwhuisdieren en voederwaarde veevoeders. Central Bureau for Livestock Feeding, Lelystad, The Netherlands.

De Walle, F. B., and J. Sevenster. 1998. Agriculture and the environment: minerals, manure and measures. Kluwer Academic Publishers, Dordrecht, The Netherlands.

Dou, Z., R. A. Kohn, J. D. Ferguson, R. C. Boston, and J. D. Newbold. 1996. Managing nitrogen on dairy farms: An integrated approach I. Model description. J. Dairy Sci. 79:2071-2080.

Dunlap, T. F., R. A. Kohn, G. E. Dahl, M. Varner, and R. A. Erdman. 2000. The impact of somatotropin, milking frequency, and photoperiod on dairy farm nutrient flows. J. Dairy Sci. 83:968-976.

Fraters, D., L. Boumans, G. van Drecht, T. de Haan, and D. W. de Hoop. 1998. Nitrogen monitoring in ground water in sandy regions of the Netherlands. Environ. Pollut. 102:479-485.

European Commission. 1991. Directive of the Council of December 12 , 1991 concerning the protection of waters against pollution caused by nitrates from agricultural sources (91/676/EEC). European Commission, Brussels, Belgium.

Groen A. F. 1988. Derivation of economic values in cattle breeding. A model at farm level. Agric. Sys. 27:195-213. 
Hanegraaf, M. C., and D. J. Den Boer. 2003. Perspectives and limitations of the Dutch Minerals Accounting System (MINAS). Eur. J. Agronomy, (accepted).

Ketelaars, J. J. M. H., and H. G. Van der Meer. 1998. Perspectives for improving efficiency of nutrient use in livestock production in the Netherlands. Pages 159-164 in Proceedings International workshop on environmentally friendly management of farm animal waste. T. Matsunaka, ed., Sapporo, Japan.

Kohn, R. A., Z. Dou, J. D. Ferguson, and R. C. Boston. 1997. A sensitivity analysis of nitrogen losses from dairy farms. Journal of Environmental Management 50:417-428.

Ministry of Agriculture, Nature Management and Fisheries. 2001. Mestkrant. Ministry of Agriculture, Nature Management and Fisheries, The Hague, The Netherlands.

Oenema, O., and C. W. J. Roest. 1998. Nitrogen and phosphorus losses from agriculture into surface waters; the effects of policies and measures in the Netherlands. Water Science and Technology 37(3):19-30.

Oenema, O., P. C. M. Boers, M. M. Van Eerdt, B. Fraters, H. G. Van der Meer, C. W. J. Roest, J. J. Schröder, and W. J. Willems. 1998. Leaching of nitrate from agriculture to groundwater: the effect of policies and measures in the Netherlands. Environ. Pollut. 102, S1:471-478.

Ondersteijn, C. J. M. 2002. Nutrient management strategies on Dutch dairy farms: An empirical analysis. Ph.D. Diss., Wageningen Univ. Wageningen, The Netherlands.

Ondersteijn, C. J. M., A. C. G. Beldman, C. H. G. Daatselaar, G. W. J. Giesen, and R. B. M. Huirne. 2002. The Dutch mineral accounting system and the European Nitrate Directive: implications for $\mathrm{N}$ and $\mathrm{P}$ management and farm performance. Agric. Ecosyst. Environ. 92(2-3):283-296.

Philipsen, B., H. Hemmer, I. Enting, L. Kuunders, and I. Vermeij. 2001. Kwantitatieve informatie veehouderij 2001-2002. Research Institute for Animal Husbandry. Lelystad, The Netherlands.
Reijneveld, J. A., B. Habekotté, H. F. M. Aarts, and J. Oenema. 2000. Typical Dutch, Zicht op verscheidenheid binnen de Nederlandse melkveehouderij. Plant Research International. Wageningen, The Netherlands.

Rigby, D., and T. Young. 1996. European environmental regulations to reduce water pollution: An analysis of their impact on UK dairy farms. Eur. Rev. Agric. Econ. 23:59-78.

Rotz, C. A., L. D. Satter, D. R. Mertens, and R. E. Muck. 1999. Feeding strategy, nitrogen cycling, and profitability of dairy farms. J. Dairy Sci. 82:2841-2855.

Schröder, J. J., H. F. M. Aarts, H. F. M. ten Berge, H. van Keulen, and J. J. Neeteson. 2003. An evaluation of whole-farm nitrogen balances and related indices for efficient nitrogen use. European Journal of Agronomy (accepted).

Tamminga, S. 1992. Nutrition management of dairy cows as a contribution to pollution control. J. Dairy Sci. 75:345-357.

Tamminga, S., W. M. van Straalen, A. P. J. Subnel, R. G. M. Meijer, A. Steg, C. J. G. Wever, and M. C. Blok. 1994. The Dutch protein evaluation system: the DVE/OEB system. Livest. Prod. Sci. 40:139-155.

Van der Kamp, A. 2002. Prognose technische, maatschappelijke en economische gevolgen. Evaluatie meststoffenwet 2002. Research Station for Animal Husbandry, Lelystad, Neth.

Van der Ven, G. W. J. 1996. A mathematical approach to comparing environmental and economic goals in dairy farming on sandy soils in the Netherlands. Ph.D. Diss., Wageningen University, Wageningen, Neth.

Van Huylenbroek, G., G. Jacobs, and P. Vanrolleghem. 2000. A simulation model to evaluate the impact of environmental programmes on dairy farms. Int. Trans. Operational Res. 7:171-183.

Van Staalduinen, L. C., M. W. Hoogeveen, H. H. Luesink, G. Cotteleer, H. van Zeijts, P. H. M. Dekker, and C. J. A. M. de Bont. 2002. Actualisering landelijk mestoverschot. 2003. Rep. no. 18. Environmental Planning Bureau. The Hague, Neth. 